Jurnal Konstruksi Hukum | ISSN: XXXX | E-ISSN: XXXX Vol. 1, No. 1, September 2020 Hal. 140-144| Available online at https://www.ejournal.warmadewa.ac.id/index.php/jukonhum DOI: https://doi.org/10.22225/jkh.1.1.2137.140-144

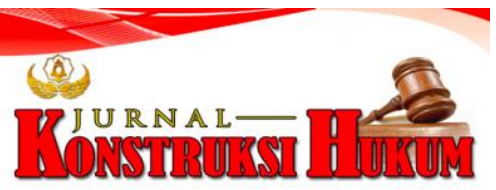

\title{
EFEKTIFITAS SANKSI PIDANA TERHADAP PENGASUH ANAK KARENA KELALAIANNYA MENGAKIBATKAN KEMATIAN DI TAMAN PENITIPAN ANAK DENPASAR
}

\author{
Gusti Ayu Putri Pratiwi, I Made Sepud, Diah Gayatri Sudibya \\ Fakultas Hukum Universitas Warmadewa, Denpasar-Bali, Indonesia
}

\begin{abstract}
Abstrak
Pesatnya perkembangan ilmu pengetahuan dan teknologi, menyebabkan banyak terjadinya kasus tindak pidana terhadap anak di bidang pelayanan pendidikan. Ada berbagai macam tindak pidana pelanggaran HAM di bidang perlindungan anak, salah satunya yaitu kelalaian dalam mengasuh dan mendidik anak. Penelitian ini bertujuan untuk mengetahui faktor-faktor yang mengakibatkan kematian pada anak asuh di TPA Princess House Childcare dan untuk mengetahui Efektifitas Sanksi Pidana terhadap pengasuh anak yang karena kelalaiannya menyebabkan kematian pada anak. Metode penelitian menggunakan tipe penelitian empiris. Pendekatan secara perundang-undangan yakni menelaah semua undang-undang dan regulasi-regulasi yang bersangkutan dengan isu hukum yang sedang ditelit, dan menggunakan pendekatan kasus. Sumber data yang diperoleh melalui informan dengan wawancara langsung dilapangan kemudian diolah dan di Analisis secara Deskriptif. Hasil penelitian menunjukkan bahwa kelalaian yang mengakibatkan kematian dapat terjadi melalui dua faktor yaitu faktor eksternal dan faktor internal. Mengenai sanksi terhadap pelaku yang mengakibatkan hilangnya nyawa seorang anak dirasakan sudah efektif dan dijalankan sesuai dengan ketentuan Sebagaimana yang diatur dalam pasal 76B Juncto Pasal 77B Undang - Undang Republik Indonesia Nomor 35 Tahun 2014 di jatuhkan Pidana Penjara selama 3 (tiga) tahun dan pidana denda sebesar RP. 50.000.000,-.
\end{abstract}

Kata Kunci: Kelalaian; Sanksi pidana; Pengasuh anak

\begin{abstract}
The rapid development of science and technology has led to many cases of criminal acts against children in the field of educational services. There are various kinds of crimes against human rights violations in the field of child protection, one of which is negligence in caring for and educating children. This study aims to determine the factors that cause death in foster children in TPA Princess House Childcare and to determine the effectiveness of criminal sanctions against child caregivers who due to their negligence cause death in children. The research method uses empirical research type. The statutory approach is to examine all laws and regulations related to the legal issue being researched, and to use a case approach. Sources of data obtained through informants with direct field interviews are then processed and analyzed descriptively. The results showed that negligence that resulted in death could occur through two factors, namely external factors and internal factors. Regarding the sanctions against the perpetrator who resulted in the loss of a child's life, it is felt that it has been effective and implemented in accordance with the provisions as stipulated in Article $76 B$ in conjunction with Article $77 B$ of the Law of the Republic of Indonesia Number 35 of 2014, imprisoned for 3 (three) years and a fine as much as RP. 50,000,000, -.
\end{abstract}

Keywords: Negligence; Criminal sanctions; Babysitter

\section{PENDAHULUAN}

Dalam peradaban manusia di kehidupan bermasyarakat, masih marak terjadinya perilaku yang menyimpang dengan peraturan hukum sehingga menyebabkan terjadinya tindak pidana. Tindak pidana yang sering dilakukan bermula karena tuntutan ekonomi, yang menjadikan Anak sebagai korban di bidang pelayanan pendidikan. Perbuatan pidana yang dilakukan harus mendapatkan sanksi yang tegas dan efektif sesuai dengan prilaku yang dilakukannya agar seluruh masyarakat bisa merasakan ketentraman dan keadilan yang merata sesuai dengan pengamalan Pancasila. Salah satu tindak pidana yang banyak terjadi mengenai pelanggaran Hak Asasi Manusia yaitu terhadap Anak. Dengan demikian diartikan bahwa seorang anak termasuk dalam subjek dan warga negara yang berhak atas perlindungan hak konstitusial dari serangan orang lain. Ada banyak macam pelanggaran HAM di bidang perlindungan Anak, diantaranya pernikahan dini, minimnya pendidikan, perdagangan 
anak, penganiayaan anak, memperkerjakan anak dibawah umur hingga kelalaian dalam mengasuh dan mendidik anak (Mayasari, 2018).

Pelanggaran kasus mengenai Anak dalam bidang Pendidikan Non formal terjadi dalam ruang lingkup Pendidikan Anak Usia Dini. Salah satu yang termasuk Pendidikan Anak Usia Dini adalah Taman Penitipan Anak (TPA). Dikatakan pendidikan anak usia dini karena ditujukan bagi anak usia 0-6 tahun. Kelalaian merupakan hal yang sering terjadi didalam pengawasan Pendidikan Anak Usia Dini. Kelalaian yang dimaksud adalah melakukan sesuatu yang seharusnnya dilakukan pada tingkatan keilmuannya tetapi tidak dilakukan tindakan dibawah standar yang telah ditentukan.

Mengenai perlindungan anak pemerintah telah menyediakan payung hukum sebagai landasan untuk menjamin kesejahteraan anak dan pemerintah dapat dengan mudah melakukan pengawasan dan perlindungan anak agar kekerasan atau hal yang tidak diinginkan pada anak dapat segera ditindak lanjuti (Sudrajat, 2011). Sesuai ketentuan yang di atur dalam Pasal 1 angka 2 Undang- Undang Nomor 35 Tahun 2014 tentang perlindungan anak diharapkan pemerintah dapat mengupayakan solusi yang tepat bagi anak sebagai korban kekerasan dan anak dapat terhindar dari diskriminasi. Indonesia sebagai negara hukum tentunya harus menciptakan kondisi serta situasi dimana seluruh rakyat dapat menikmati dan merasa aman dari tindakan-tindakan yang tidak sesuai dengan kaidah dari nilai hukum (Fadilah, 2019). Hukum dalam fungsinya mengatur seluruh aspek kehidupan berbangsa dan bernegara dapat memberikan kontribusi secara maksimal kepada pelaksanaan jika aparat hukum dan seluruh lapisan masyrakat tunduk dan taat pada norma hukum. Dewasa ini kasus yang sedang marak diperbincangkan terletak dalam dunia pendidikan baik formal maupun nonformal. Penelitian ini dilakukan di bidang pendidikan nonformal yang terletak di di Taman Penitipan Anak Princess House Childcare Denpasar, karena dalam kasus tersebut telah terjadinya kelalaian dari pengasuh yang mengakibatkan hilangnya nyawa seorang bayi. Selain mengacu kepada KUHP dan Undang-Undang Nomor 35 Tahun 2014 tentang perlindungan anak. Digunakan juga UndangUndang Nomor 20 Tahun 2003 tentang sistem Pendidikan Nasional sebagai acuan perbandingan untuk menguatkan argumen penelitian yang bersangkutan dengan kasus di Taman Penitipan Anak Princess House Childcare Denpasar.

Penelitian ini bertujuan untuk mengetahui faktor yang mengakibatkan kematian pada anak dan efektifitas dari sanksi pidana yang diterapkan bagi pelaku tindak pidana kelalaian di Taman Penitipan Anak Princess House Childcare Denpasar, mengingat banyaknya terjadi kasus yang menjadikan anak sebagai korban di bidang pelayanan pendidikan itu sendiri.

\section{METODE PENELITIAN}

Tipe penelitian yang digunakan pada penelitian ini yaitu bersifat penelitian hukum empiris, dalam hal ini terjun langsung ke masyarakat dengan melakukan telaah pada kasus-kasus yang berkaitan dengan isu hukum yang dihadapi. Sumber data yang digunakan adalah sumber data primer dan sumber data sekunder. Teknik pengumpulan data dengan cara studi pustaka untuk mengumpulkan data sekunder berupa dokumentasi dan studi lapangan untuk mengumpulkan data primer dapat berupa wawancara berhadapan langsung dengan pejabat serta pihak pemberi informasi yang disebut juga informan. Data-data tersebut kemudian dikumpulkan, diolah, dianalisis berdasarkan argumentasi hukum yang di dapat melalui informan mengenai kasus yang sedang diteliti.

\section{HASIL DAN PEMBAHASAN}

\section{Faktor-Faktor yang Mengakibatkan Kematian pada Anak Asuh di TPA Princess House Childcare Denpasar}

Kelalaian sering dinyatakan sebagai faktor utama penyebab dari timbulnya perbuatan pidana, dalam hal ini kelalaian yang di timbulkan akibat perbuatan pidana telah terjadi di dalam dunia pendidikan Non formal (Hendrawan et al., 2015). Berkaitan dengan kasus kelalaian yang mengakibatkan hilangnya nyawa seorang anak di Taman Penitipan Anak Denpasar pemerintah telah memberikan payung hukum di bidang pendidikan dengan mengeluarkan Undang-Undang Nomor 20 tahun 2003 tentang Sistem Pendidikan Nasional (Sisdiknas). Pemerintah pusat maupun daerah diharapkan berperan secara langsung dalam memberikan perlindungan hukum terhadap anak di dalam bidang pelayanan pendidikan formal maupun nonformal agar lebih berkualitas. 
Taman Penitipan Anak Princess House Childcare Denpasar ini yang beralamatkan di Jalan Badak Sari 1 Denpasar memiliki lokasi yang cukup strategis karena dekat dengan pusat Kota Denpasar, meskipun rumah tersebut memiliki dua lantai belum dapat dikatakan layak untuk di jadikan Taman Penitipan Anak karena, rumah tersebut tidak memiliki halaman yang cukup luas untuk ruang gerak dan sarana prasarana edukasi bagi Anak asuh yang dititipkan. Hal tersebut sangat menyimpang dari ketentuan yang diatur dalam Pasal 45 ayat (1) Undang- Undang Nomor 20 Tahun 2003 tentang sistem pendidikan Nasional. Menurut rangkuman dari keterangan seluruh Informan, kelalaian yang mengakibatkan hilangnya nyawa seorang Anak di Taman Penitipan Anak Princess House Childcare sangat mungkin terjadi mengingat pengasuh yang dipekerjakan tidak memiliki standar dan kemampuan khusus di bidang perawatan anak. Terlebih Taman Penitipan Anak tersebut belum mengantongi izin resmi dari Pemerintah Pusat maupun Pemerinta Desa, sehingga pemerintah tidak bisa memberikan pelatihan dari ahli gizi dan juga tidak dapat mengevaluasi pengasuhan yang diberikan terhadap anak asuh di Taman Penitipan Anak tersebut. Kealpaan merupakan bentuk kesalahan daripada sikap batin seseorang dan sikap batin yang demikian adalah berwarna, artinya selalu dihubungkan dengan sikap batin terhadap perbuatan yang dipandang dari sudut hukum adalah keliru (Moeljatno, 2002)

Secara umum faktor yang dapat terjadi karena kelalaian yang mengakibatkan kematian di Taman Penitipan Anak Princess House Childcare Denpasar terdiri dari dua kemungkinan yaitu Faktor Internal dan Faktor Eksternal. Faktor internal adalah faktor yang berasal dari diri atau pribadi seseorang itu sendiri. Faktor internal penyebab dari kelalaian di Taman Penitipan Anak di Denpasar berasal dari kurangnya kesadaran dan kepatuhan dalam menerapkan standar pendirian Taman Penitipan Anak sesui dengan peraturan yang berlaku dalam membentuk struktur pengasuhan yang dilakukan oleh pemilik Taman Penitipan Anak Princess House Childcare Denpasar. Kelalaian pada dasarnya kurangnya kehati-hatian, kurangnya kesiapan dan tenaga ahli yang dimiliki pengasuh untuk memberikan pelayanan secara intensif pada masing-masing anak asuh di setiap usia sesuai dengan prosedur. Faktor tersebut diperkuat oleh pernyataan dari salah satu karyawan yang pernah bekerja sebagai pengasuh di Taman Penitipan Anak tersebut, yang mengaku bahwa hampir seluruh pengasuh yang dipekerjakan tidak memiliki kemampuan khusus di bidang perawatan anak dan belum pernah mengikuti pelatihan tentang ahli gizi atau sejenisnya yang diperlukan dalam kualifikasi pengasuh pendidikan anak usia dini.

Sedangkan Faktor eksternal adalah faktor yang timbul dari luar diri individu atau seseorang. Faktor eksternal karena kelalaian yang menyebabkan kematian di TPA Princess House Childcare Denpasar memiliki 2 faktor yaitu faktor sumber daya dan faktor ekonomi. Keadaan sumber daya perlu diperhatikan dalam menjalankan sebuah tempat penitipan Anak yang berbasis Pendidikan Anak Usia Dini. Dalam Point sumber daya ini yang menjadi salah satu faktor eksternal dapat dilihat dari tidak adanya pemfasilitasan dari pihak pemilik terhadap seluruh pengasuh untuk mengikuti pelatihan dari ahli gizi agar memiliki sertifikat dan keprofesionalan dalam menangani anak asuh sesuai dengan usianya. Terlebih lagi belum adanya izin untuk mendirikan Taman Penitipan Anak secara lengkap, sehingga pemerintah tidak dapat memonitoring dan melakukan evaluasi untuk memastikan bahwa tenaga pengasuh berkompeten dalam memberikan pelayanan kepada anak asuh sesuai dengan apa yang seharusnya mereka peroleh. Sedangkan faktor ekonomi yang menjadi dilema antara pemilik maupun pengasuh bayi juga sangat mempengaruhi terjadinya kematian pada bayi di Taman Penitipan Anak Princess House Childcare Denpasar karena, tuntutan ekonomi yang besar mengharuskan mereka menjalani pekerjaan tanpa mengidahkan peraturan yang semestinya. Pemilik usaha taman Penitipan Anak tidak memperhatikan segi keamanan dan kenyamanan dari masing-masing pengasuh dalam hal pengawasan pada sejumlah anak yang dibebankan kepada satu orang pengasuh sehingga pengasuh harus memberikan pelayanan kepada anak asuh meskipun dengan cara yang kurang tepat demi memenuhi kebutuhan ekonominya.

Kebijakan atau upaya penanggulangan kejahatan pada hakikatnya merupakan bagian integral dari upaya perlindungan masyarakat (social defence) dan upaya mencapai kesejahteraan masyarakat (social welfare) (Soedharto, 1981). Hasil observasi di lapangan, upaya penanggulangan yang dapat dilakukan yaitu berfokus kepada pemerintah desa untuk lebih gencar melakukan monitoring kepada seluruh kegiatan yang dilakukan oleh masyarakat terutama masyarakat pendatang yang baru mendirikan usaha dibidang pelayanan jasa atau dibidang pelayanan pendidikan seperti Taman 
Penitipan Anak. Upaya yang paling sederhana terletak dari kesadaran dan kepedulian masyarakat, orang tua ataupun para pendiri usaha yang terkait untuk ikut melakukan pengawasan apabila terjadi perbuatan yang menimbulkan kejanggalan agar segera melaporkan kepada pihak yang berwajib sehingga hal yang tidak di inginkan terhadap anak khususnya tidak terjadi.

\section{Efektifitas Sanksi Pidana terhadap Pengasuh Anak yang karena Kelalaiannya Mengakibatkan Kematian Pada Anak}

Perbuatan pidana merupakan perbuatan yang dilarang oleh suatu aturan hukum larangan yang mana disertai ancaman (sanksi) yang berupa pidana tertentu, bagi barangsiapa melanggar larangan tersebut (Waluyo, 2008) Hukum Pidana ini nantinya diharapkan bahwa hukum pidana dapat melindungi masyarakat terhadap bahaya yang ditimbulkan oleh orang yang melakukan kejahatan itu (Widyanti, 1987).

Sanksi pidana pada dasarnya merupakan suatu sarana atau penjamin seseorang dapat bertanggungjawab dari suatu perilaku kejahatan yang dilakukan (Afifah, 2014). Sanksi pidana itu sendiri dapat diartikan dengan istilah pidana dan dapat di artikan dengan istilah yaitu hukuman, pemidanaan, pemberian pidana dan hukuman pidana. Kealpaan atau kelalaian terdapat apabila seseorang tetap saja melakukan perbuatan itu meskipun ia telah mengetahui atau menduga akibatnya. Dapat diduganya suatu akibat terlebih dahulu oleh pelaku maka hal tersebut adalah syarat mutlak suatu akibat yang tidak dapat diduga terlebih dahulu maka tidak dapat dipertanggungjawabkan kepadanya sebagai kealpaan (Sudarsono, 2007). Kelalaian yang menyebabkan kematian pada anak dapat terjadi di berbagai faktor. Salah satunya adalah dibidang pelayanan kesehatan, karena anakanak juga rentan mengalami kekerasan di tempat pelayanan kesehatan bahkan di bidang pendidikan pun mengalami hal serupa yang disebabkan oleh perlakuan diskriminasi karena anak belum mampu mengungkapkan apa yang dirasakannya sehingga seringkali anak pasrah menerima berbagai perlakuan yang diterima dari pengasuh atau pendidik. Tindak pidana kelalaian memiliki pengertian yang sangat abstrak dari peristiwa-peristiwa yang kongkrit dalam lapangan hukum pidana. Sudah seharusnya dalam pelanggaran tindak pidana kelalaian deberlakukan hukuman sanksi yang tegas sesuai dengan yang diatur dalam pasal 359 Kitab Undang- Undang Hukum Pidana sebagai acuan untuk lebih berhati-hati dalam bertindak dan melakukan sesuatu untuk menghindari terjadinya perbuatan karena Kelalaian yang berujung menimbulkan sanksi Pidana.

Sanksi pidana yang dijatuhkan terhadap pelaku tindak pidana kelalaian yang menyebabkan kematian pada anak mengacu pada pasal 359 KUHP dimana dalam bunyi pasal tersebut mengatur bagi pelaku tindak pidana kealpaan diancam dengan pidana penjara paling lama lima tahun atau pidana kurungan paling lama satu tahun. Berdasarkan putusan pengadilan Negeri Denpasar Nomor: 844/Pid.Sus/2019/PN.DPS maka Hakim dalam menjatuhkan putusan, Khususnya terhadap Taman Penitipan Anak Princess House Childcare Denpasar tetap berpegang teguh dengan ketentuan pasal 359 KUHP yakni terdakwa selaku pemilik Taman Penitipan Anak tersebut melakukan tindak pidana dengan dikenakan sanksi yang termuat dalam pasal 76B Juncto Pasal 77B Undang Undang Republik Indonesia Nomor 35 Tahun 2014 tentang Perlindungan anak. Hakim dalam memutus perkara kasus kelalaian yang mengakibatkan hilangnya nyawa seorang bayi di Taman Penitipan Anak Denpasar, menetapkan Terdakwa selaku penanggungjawab dari Taman Penitipan Anak tersebut dijatuhi hukuman Pidana Penjara selama 3 (tiga) tahun dikurangi selama terdakwa berada dalam tahanan dan pidana denda sebesar Rp. 50.000.000,00 (lima puluh juta rupiah) subdisidiair 2 (dua) bulan kurungan dan terdakwa dihukum untuk membayar biaya perkara sebesar Rp. 2000,- (dua ribu rupiah).

Berdasarkan keputusan hakim diatas, menurut pandangan Penulis dalam hal penerapan sanksi terhadap pelaku tindak pidana yang dijatuhkan dipandang Efektif karena dijalankan dan diterapkan sesuai dengan payung hukum yaitu Undang-Undang Nomor 35 Tahun 2014 tentang perlindungan anak karena anak merupakan penerus generasi bangsa yang harus diperhatikan dan dijaga tumbuh kembangnya maka bagi pelaku yang memberikan diskriminasi atau penelantaran terhadap anak hingga mengakibatkan hilangnya nyawa semestinya dihukum maksimal masa tahanan sesuai dengan Undang-Undang yang mengatur serta direkomendasikan Pasal 71 Undang-Undang Sisdiknas yang mengatur sanksi bagi pelaku pendiri satuan pendidikan formal maupun nonformal yang belum memperoleh izin pemerintah untuk memberatkan pelaku. 


\section{SIMPULAN DAN SARAN}

\section{Simpulan}

Berdasrakan hasil penelitian di atas, disimpulkan bahwa faktor yang mengakibatkan kematian pada anak asuh di TPA Princess House Childcare adalah faktor kelalaian baik yang diakibatkan oleh pengasuh maupun pemilik sebagai penanggungjawab dari Taman Penitipan Anak itu sendiri. Ada dua faktor yang dapat menjadi penyebab kematian karena kelalaian di Taman Penitipan Anak tersebut yaitu faktor internal dan eksternal. Faktor internal berasal dari diri seseorang itu sendiri yang tidak memiliki pengalaman, kurang kehati-hatian, kurang kesiapan atau pelatihan dalam menangasi masalah dan tidak profesional dibidang yang sedang ditangani. Sedangkan faktor eksternal itu sendiri sesuatu yang dapat timbul dari luar diri seseorang, dapat dilihat dari lingkungan, sumber daya dan aspek ekonomi. Kemudian, efektifitas Sanksi Pidana terhadap pengasuh anak yang karena kelalaiannya menyebabkan kematian pada anak merupakan salah satu bentuk kesalahan yang timbul karena pelakunya tidak memenuhi standar yang telah diatur dalam Undang-Undang. Mengenai kelalaian diatur dalam pasal 359 Kitab Undang-Undang Hukum Pidana dan Pemerintah telah memberikan payung hukum dengan mengeluarkan Undang-Undang Nomor 35 tahun 2014 tentang Perlindungan Anak. Dalam putusan Hakim telah menetapkan pemilik sekaligus penanggungjawab Taman Penitipan Anak sebagai tersangka dengan menjatuhkan pasal 76B Juncto Pasal 77B Undang Undang Republik Indonesia Nomor 35 Tahun 2014 tentang Perlindungan anak sebagai sanksi pidana. Sistem Pemidanaan yang dijatuhkan dirasakan sudah efektif karena diterapkan dan berjalan sesuai dengan ketentuan yang diatur oleh Undang-Undang Perlindungan anak.

\section{Saran}

Adapun beberapa saran yang hendak disampaikan yakni kepada Pemerintah khususnya aparat penegak hukum seperti Hakim, Jaksa dan Polisi dalam menangani masalah mengenai Tindak Pidana Anak harus lebih memberikan perlindungan hukum terhadap anak agar menghindari segala kemungkinan yang tidak diharapkan menjadikan anak sebagai korban dalam tindak pidana dan perlindungan yang diberikan tidak hanya terhadap pelaku, sehingga aparat penegak hukum mencerminkan keadilan, kepastian dan kemanfaatan hukum bagi masyarakat. Kemudian, saran bagi para orang tua supaya lebih selektif dalam memilih Tempat Penitipan Anak, turut serta mengawasi proses perkembangan anak di dalam pengasuhan dan menjalin komunikasi yang baik antara pengasuh maupun seluruh pihak yang berada di dalam ruang lingkup Taman Penitipan Anak untuk menjamin tumbuh kembang anak juga terhindar dari tindak pidana anak. Terlebih kepada masyarakat, kiranya bisa turut serta membantu mengawasi setiap lembaga atau usaha di bidang pelayanan pendidikan formal maupun nonformal dan segera melaporkan baik hal kecil maupun besar yang menyimpang atau bertentangan dengan hukum yang kepada pihak yang berwajib, sehingga dapat memperkecil kemungkinan terjadinya tindak pidana.

\section{DAFTAR PUSTAKA}

Afifah, W. (2014). Pertanggungjawaban Pidana Anak Konflik Hukum. DIH: Jurnal Ilmu Hukum, 10(19), 48-62.

Fadilah, N. (2019). Tantangan dan Penguatan Ideologi Pancasila dalam Menghadapi Era Revolusi Industri 4.0. Journal of Digital Education, Communication, and Arts, 2(2), 66-78.

Hendrawan, M. B., Syahrin, A., Ginting, B., \& Mulyadi, M. (2015). Hubungan antara Kesengajaan terhadap Pertanggungjawaban Pidana dalam Kasus Kecelakaan Lalu Lintas di Jalan yang Menyebabkan Hilangnya Nyawa Orang Seseorang. USU Law Journal, 3(1), 56-73.

Mayasari, D. E. (2018). Perlindungan Hak Anak Kategori Juvenile Delinquency. Kanun Jurnal Ilmu Hukum, 20(3), 385-400.

Moeljatno. (2002). Asas-asas Hukum Pidana (2nd ed.). Rineka Cipta.

Soedharto. (1981). Kapita Selekta Hukum Pidana. Alumni.

Sudarsono. (2007). Kamus Hukum (5th ed.). PT. Rineka Cipta.

Sudrajat, T. (2011). Perlindungan Hukum terhadap Hak Anak sebagai Hak Asasi Manusia dalam Perspektif Sistem Hukum Keluarga di Indonesia. Kanun: Jurnal Ilmu Hukum, 13(54), 111-132.

Waluyo, B. (2008). Pidana dan Pemidanaan. Sinar Grafika.

Widyanti, N. (1987). Kejahatan Dalam Masyarakat dan Penyegahannya. Bina Aksara. 